\title{
Health, Social Determination, Living Conditions of Liver Transplanted Patients from the State of Amazon
}

\author{
Rosiane Pinheiro Palheta ${ }^{1,2, *}$, Maria Geralda Correia Ozorio ${ }^{3}$, Mileyde Carolaine Magalhaes dos Santos $^{3}$ \\ ${ }^{1}$ Municipal Department of Health and Social Work, Hospital Adriano Jorge Foundation, Brazil \\ ${ }^{2}$ The Program for Support of Scientific Initiation, Public Health of the Amazon, Brazil \\ ${ }^{3}$ Scientific Initiation Support Program of Adriano Jorge Hospital Foundation (PAIC), Public Health of the Amazon, Brazil
}

Copyright $(\subset 2015$ by authors, all rights reserved. Authors agree that this article remains permanently open access under the terms of the Creative Commons Attribution License 4.0 International License

\begin{abstract}
In the Amazon, the organ and tissue transplant service was created in 2013 with the implementation of hepatic transplantation outpatient ward at Adriano Jorge Hospital Foundation due to the high rate of cases and the rising cost to the State. The work results from a survey conducted within the Support of Scientific Initiation Program whose goal is to analyze the social determinations in the assisted cases. It had performed a documentary and field research with the use of interviews and observation as data collection technique. The results show the social conditions as important factors that must be taken into consideration in the process of becoming the able patient for transplantation, however, a network support is still needed to be built.
\end{abstract}

Keywords Transplantation, Social Issues, Living Conditions

\section{Introduction}

The article results of research carried out within the Foundation's Undergraduate Research Program Hospital Adriano Jorge- PAIC / FHAJ in the Amazon State and propose a reflection on the implications of social issues in the liver transplant process. Given the importance of this therapeutic procedure that presents itself as a new demand in the health field and in the work processes of a social worker, in its multiple dimensions. It is important to consider the transplant patient as a subject of rights who requires specific public policies, among them the public Policy health and social assistance.

The transplantation of organs and tissues is inserted into the Health Public Policy scenario, as a citizenship right the State's setup duty and civil rights guaranteed in the Constitution of 1988 is the result of demands of various segments of society through the tripod: health, social security and social assistance.

Due to the high number of cases of chronic liver disease in the state of Amazonas, and the high cost of state with treating patients outside of domicile (PDT), the hepatic transplantation service of the State was created in March 2013 with the implementation of the outpatient transplant Hospital Adriano Jorge -FHAJ foundation. This which provides assistance and monitoring of patients through a multidisciplinary team in which adopts the professional social work, which has multiple forms of expression of the social question as the scientific object of his daily work.

It is from this perspective of the patient the subject of rights and research is used to uncover the reality and point out how social issues are determining the user's health from this arises the on research, because social issues and their expressions as housing, sanitation and income directly affect the quality of post-transplant life, since such factors are conditioning and determining to the health.

In which situations such conditions have influenced the health treatment and recovering from the transplanted users? Which difficulties, demands and interventions are necessary to improve such conditions?

\section{Methods Described as an Objective Manner}

To any scientific research, it is necessary that the researcher is anchored in theoretical knowledge to be viable the production of knowledge, the importance of this knowledge consists that the researcher, to master the theory, is focused to its work methodology. Theoretical knowledge is the basis for the method which will seek to highlight the reality.

That point of view allows the researcher to notice several coverage, dimensions and plurality that a same object can have. The first stage of the research was the bibliographic survey which also indicates a lack of studies about the social determinants in the treatment and recovering of transplanted patients.

The study was conducted at Hospital Adriano Jorge Foundation from the analysis of documents and records and 
social records of patients in the transplant clinic available on this foundation and the records of the Treatment Program Outside Domicile - PDT, from the Amazon State from 2010 to 2014 .

The documentary research was carried out from the analysis of the records, medical records and social records of patients in the transplant ward of Hospital Foundation Adriano Jorge -FHAJ. There were also analyzed documents of patients in the treatment program records Outside Domicile - PDT, the State of Amazonas.

There were identified 194 patients post - transplant, through the Treatment Outside of Address (PDT) in the State of Amazonas, 138 were treated at the transplant clinic of Adriano Jorge Hospital Foundation (FHAJ) of which only three were transplanted on this foundation in 2014 , this because only this year, the liver transplants have been carried out in the Amazon. To trace the profile of patients, a sample of $45 \%$ was used of the total cases followed by Social Services for a total of 62 patients.

An observation has been made as a data collection instrument in all stages of the field research once the researchers themselves participated in all stages of the research towards participatory research. The goal is to identify on-the-spot how the social factors such as: housing conditions and basic sanitation plus the reality of patients already transplanted interfere before, during and after transplantation.

The method of participatory research emerges opposed to traditional research, as a possibility that individuals and groups of the working classes were direct participants of knowledge. Brandão (1984) writes that "The relationship of participation of scientific practice in the political work of the working class challenges the researcher to see and understand such classes, their subjects and their worlds" for the author there is where resides the invention of participatory research.

OLIVEIRA (1996), [6] in turn when referring to the participant observation as a strategy reflects that it is constituted as the one responsible for characterizing the fieldwork in anthropology, singling it as a discipline in the social sciences, but adds that it is in acts of looking and listening, while functions of a very peculiar observation gender, which allows researchers to interpret the society and the culture of the other "inside", in its true interiority.

Semi-open interviews were conducted with six (06) patients who have already performed the transplant to enable the analysis of how social conditions has set in determinant for the treatment and rehabilitation of health. For the following criteria define the subjects were used: First agree to join the study, be Adriano Jorge Hospital Foundation ambulatory user and be natural from the state countryside whose traveling to the city of Manaus is one of the main problems faced by patients to continue the treatment.

The addition of the latter criterion is due to the fact that most cases followed by FHAJ social service is from the countryside of the State of Amazon characterized as remote places and accessed only by plane or boat which shifting is time-consuming and costly. A data collection was conducted in the municipality of Eirunepé, primarily because of the difficulty that users face in moving to the city of Manaus for outpatient treatment and secondly, to enable on-site observation of the social situation and housing of users after transplantation and enable the analysis of how these issues have influenced the treatment and recovery after transplantation.

Thus, six patients that were using PDT were interviewed for the procedure in Fortaleza between the years of 2012 to 2014. The interviews were performed in the house of patients after reading agreement and signing the Free Informed Consent Term. A tape recorder was used to absorb more objectively the lines of respondents.

It's possible to listen to a special hearing of all the sayings of Oliveira (1996), who explains that the researcher must know how to listen. The author refers to an illusory field of interaction between interviewer and interviewee, when one asks questions seeking specific answers that deplete the cognitive act. For him the researcher in a dialogical relationship, should turn informant in speaker, in this case a new relationship modality can and should take place. After the interviews, the data were tabulated, discussed and analyzed by the research team.

\section{Analysis and Discussion}

The profile shows that $66.7 \%$ of the cases studied were male and $33.3 \%$ female. The majority $66.7 \%$ are between 41 and 60 years and $33.3 \%$ are in the range $31-40$ years. After transplantation all interviewed patients were affected by health problems, among which stands out: allergy, diabetes, ringworm, skin cancer and intestinal infection.

None of the patients have access to the sewage system, only $50 \%$ have access to clean water and the majority $83.3 \%$ do not have electricity. The income of $66.7 \%$ does not reach a minimum wage; $33.3 \%$ earn four minimum wages and the majority of these $66.7 \%$ survive from the assistance benefits from the federal government. These data indicate social issues as an important aspect of the profile of the subject.

Respondents were asked about the major difficulties experienced in the recovery process after transplantation. The table below shows the listed problems.

Table 1. Difficulties in recovering

\begin{tabular}{|c|c|c|}
\hline Respostas & Número & $\%$ \\
\hline Financial failure & 2 & 33,2 \\
\hline Problems in biliary tract & 1 & 16,7 \\
\hline Clot brain & 1 & 16,7 \\
\hline $\begin{array}{c}\text { Would feed better and control the } \\
\text { diabetes }\end{array}$ & 1 & 16,7 \\
\hline Acquisition of a virus that led to coma & 1 & 16,7 \\
\hline Total & 6 & 100 \\
\hline
\end{tabular}

Source: Field research, 2014

The answers show that $50 \%$ of respondents reported that the problems occurred in the recovery of health after 
transplantation are related to economic and social problems. The other $50 \%$ are related to immune factors and the patient's weak position in relation to its overall health.

The answers are in line with the discussions on the social determinants of health that incited the country from the end of the 70's, where social issues are now included as an important element that determines the health where the issue has become the subject of a commission on social determinants of health by the World Health Organization (WHO).

The authors point out the lack of conceptual clarification and meaning of the term social determination, which limits their explanatory power, causing the categories are placed as predecessors situations and put further that the term "health" while complex object also lacks a conceptual development able to approach it in its diversity and uncertainty. (Tambellini and SCHUTZ, 2009). [9]

Another issue addressed in the interviews was about whether or not there is influence of the socioeconomic situation in the transplantation process, before, during and after the procedure and how such situations are influencing and are influenced by everyday living conditions. All responses were positive and is mainly aimed at related to diet and lack of money for travel and conducting regular medical appointments. Among the answer stands out: Difficulties in acquiring the diet; lack of enough money to buy drugs that are not dispensed by the city; Lack of conditions for the purchase of tickets to go to appointments; Long wait for PDT; poor living conditions, lack of basic sanitation, among others.

It is observed that poverty is one of the common aspects in case studies and should be taken into account at the time of nomination of patient waiting. This is because the recovery of the transplanted patient requires housing conditions and sanitation appropriate for proper treatment and maintaining health.

This is an issue that deserves to be highlighted in discussions of multidisciplinary health teams working in transplant policy. Take into account social issues in the promotion process, protection and recovery of health of these patients, and all, look at how such issues that affect the health of patients after transplantation.

Such conditions have led to inequality in access and to the treatment success. It starts from the assumption that social conditions are substantively relevant and important to users or become unsuitable for transplantation because the social conditions directly influence the recovery process in the post-transplant. Thus, it is important that these conditions should be taken into account when making a patient able for transplantation, it is necessary to take into consideration not only the biological and physical factors, but social factors as determinants for successful treatment.

The table below summarizes what patients consider to be major difficulties in everyday life involving the health care process:
Table 2. Which interferes in the treatment?

\begin{tabular}{|c|c|}
\hline Difficulties & Implications \\
\hline transport necessity & Absence to visits and examinations \\
\hline Basic sanitation lack & $\begin{array}{c}\text { It might help users to acquire } \\
\text { infectious diseases. }\end{array}$ \\
\hline $\begin{array}{c}\text { Difficulty in acquiring the } \\
\text { prescribed diet }\end{array}$ & $\begin{array}{c}\text { Contributes to the fungus infection, } \\
\text { malnutrition. }\end{array}$ \\
\hline $\begin{array}{c}\text { Physical effort that daily } \\
\text { activities require }\end{array}$ & $\begin{array}{c}\text { Suffers from abdominal pain, runs } \\
\text { out of working }\end{array}$ \\
\hline $\begin{array}{c}\text { Exposure to the sun due to the } \\
\text { farmer working }\end{array}$ & $\begin{array}{c}\text { Suffers from abdominal pain, feeling } \\
\text { tired, skin lesions. }\end{array}$ \\
\hline $\begin{array}{c}\text { Difficulty in acquiring all } \\
\text { medications }\end{array}$ & No medication to be taken. \\
\hline
\end{tabular}

Source: Field research 2014

The table and answers above were prepared and grouped according to the testimonies of interviewees. The difficulties listed result in negative situations for patients in everyday life that on the table above were categorized as implications of such situations. In all the answers, we can see that the situations of everyday life and work and even on the treatment are determinants of health and disease in transplant patients: buy medicine, transportation acquisition to travel to Manaus when there is medical consultation, the necessity of a healthy and balanced diet, work in agriculture puts the worker to the risks of sun exposure and fatigue.

What I would like from TFD was my ticket here to Manaus that would greatly improve the situation, because the ticket from here to Manaus sometimes that they are very expensive and I can't handle with that situation, because with the salary that I gain and to pay a ticket from here to Manaus and the host there's no way to maintain me. That's the difficulty. (Respondent 01, 2014).

The interviewee expressed concern about the situation of their treatment because the majority of patients being treated in Manaus lies on the inside and the equidistance is one of the most common problems that affect the treatment of high complexity of SUS in the Amazon. The speech shows this difficulty since the interviewee resides in the city of Eirunepé which is situated 1939 kilometers from the capital of Amazonas. This distance makes it difficult to treat because the shifting is done only by boat or air, raising the cost of treatment to patients who often do not have the help of PDT for pre-scheduled appointments.

In this connection the geography, territorial and social issues are crucial in the health-disease process in the reality of transplantation policy, especially those who live in the Amazonian cities and this issue must be analyzed taking into account the existing social and regional inequalities in the country. As Almeida Filho points out (2009) [10] it is necessary to formulate more systematically and precisely the social determinants of health, and it should make use of the theoretical problems of social inequality, as this needs a more relevant theoretical clarity. For this, it takes back the classics like Rawls and Amartya Sen. To him, there is a huge gap and lack of interest in the dominant discourse about the 
topic social inequality in health and that would explain the weakness of the concept of determination.

To address the issue from the point of view of theoretical critique, it means an initial effort, to know in depth to overcome more effectively, determinants, structure and effects of social inequalities in health. Ultimately, this implies a conceptual construction work and mobilization to political action able to make the differences more equal (or less unequal), in other words, to promote equality in difference, making them to reduce the role of gender differences, generation, ethnic-racial, cultural and social class as determinants of economic inequality, social and health "(ALMEIDA FILHO, 2009, p. 368).

In the debate on the social determinants of health, Teixeira (2009), [11] introduces the topic of social determination of individuals, because it considers that the health, independent of the meaning attributed to it, is not separated from the general determination of people's lives that is determined by the position they occupy in society and not just the major economic structures, the diversity of cultural patterns, everyday living conditions, ethical values, interpersonal relationships, among others, but above all the individual itself.

Within their material and spiritual heritage and the real conditions of their lives, individuals always have the choice among several alternatives, such as a distinctive element and in eliminable of their behavior. This means that the sequence of social determinations, from the most general characteristics of society, even the most particular of small groups and interpersonal relations, according to the legend, but these are active in choosing their actions. This choice and the individual and collective commitment that can derive therefrom are critical moments for the transformation of social structure itself, the patterns of relationships and values that make up a given society "(TEIXEIRA, 2009, p.382).

To him, environmental and housing conditions, access to food and other basic goods, engagement, development and conditions of work activities, among other things, can cause serious damage to people's health and that such conditions are beyond the control as they are determined by the social hierarchy and social division of labor and income. In the case of this study and taking into account the Amazon reality, added the geographical factors, territorial and access the politics of states and municipalities.

In the same direction, Helman (2010) [12] says that socioeconomic factors contribute to inequalities in health, and take, as an example, Black Report, 1982, which studies health disparities in the United Kingdom, which clearly shows that health correlated with income and the higher classes of people suffered fewer illnesses and lower mortality, compared to the most popular classes.

The contribution of the authors lies in the analysis of three levels: knowledge, linked to the process of appropriation of knowledge by the working classes; the health-disease resulting from both objective and subjective living conditions; and the practice of intellectual industry, in Gramscian approach of organic unity and commitment.

To those authors, the simplest determinants of health is the "professional medical care", consumed as a commodity which is consumed the attention of professionals and not its outcome and as a specialized value of work, not only on the doctor, but on the Deontologist, Nurse, Psychologist, Social Worker, Administrator, in short, all the agents in this industry, whose workforce is incorporated directly by capitalism.

\begin{abstract}
Health workers within the SUS, should develop more politicized activities, especially those participating in the PSF and other peripherals programs. However, what can be verified is that many of these programs and projects are financed by international agencies like the World Bank, with demagoguery and populism welfare, confuse the true causality of disease and its relationship to the production process, with persistent deterioration of strength of work. All this almost aseptic environment, which isolates the ideological factors beyond the everyday forum for discussion, enables the monitoring and control of individuals belonging to the most politicized middle class: students, professionals and even different social groups in their own community (GARRAFA and CÓRDON, 2009 , p. 394).
\end{abstract}

The design of authors to scientific and technical activity of certain professional sectors of health services and SUS, is alienated, legitimizing and breeding of alienated and alienating process, requiring a "negating political praxis" of these processes.

They underscore the importance of social determinants of health, however, without disregarding the construction of a new intervention negating attitude of the status quo, includes taking new attitudes on the part of the professional workforce in the health sector still remembering the importance of managers and service network committed to the populations and service users.

Therefore respondents pronounced themselves about the treatment received and positioned themselves about the transplant policy in SUS making suggestions to improve it. The answers are tabulated below:

Table 3. Which can improve transplant policy in Brazil

\begin{tabular}{|c|c|c|}
\hline Answers & Number & $\%$ \\
\hline $\begin{array}{c}\text { Improve policy between state and } \\
\text { municipality }\end{array}$ & 1 & 16,7 \\
\hline $\begin{array}{c}\text { Extend the capabilities for } \\
\text { transplantation }\end{array}$ & 1 & 16,7 \\
\hline Campaigning to organ donation & 4 & 66,6 \\
\hline Total & 6 & 100 \\
\hline
\end{tabular}

Source: Field research, 2014

Respondents positively evaluated the transplant policy stating that the policy is very important for people who need 
the procedure and linking the same with "saving lives". The excerpt below clearly shows the importance of policy and the proper treatment received by the professional staff.

I have no complaints, I like our doctors, the people serving us and it has been very good, there is no shortage of medication (...) I think yes, the only difficulty I have is in my ticket here Eirunepe to Manaus, far from Manaus to Fortaleza I have no way to complain at all. The complaint I have is the Eirunepé tickets to Manaus that we have nothing. (Interviewed 2)

The interviewee referring to the team and to politics itself makes it clear that is very well treated, doctors are excellent professionals, the social worker accompanies patients and everything needed in terms of tickets and as the rights to access to health, are made possible through this professional. The interviewee is pleased, however, because of the place of residence, as well as other users in the state, the respondent suffers from a distance because the monitoring in the clinic in Manaus, requires shifting and spending on transport, which in many cases it is not possible for the PDT or the situation results in shortages and / or delays in medical appointments.

Thus, when respondents $(16 \%)$ of the total state that the policy of state and municipality must be improved, means that national policy is not compatible with local politics because when they need to match the municipality for aid as displacement, aid housing and other supporting benefits to treatment, do not receive support from municipal governments. In the meantime, it is necessary the intervention of the social team assistant with the network of social services and social policies for the realization of the rights of users who are interfering in the treatment and recovery of health.

According to Table 3 the majority of respondents (66\%) cited campaigning for organ donation to improve transplant policy in Brazil. This fact is associated with delay in transplant because it depends on availability and compatibility organ to be transplanted and yet all the logistics for transport in case of the existence and compatibility. There are numerous campaigns, including programs of health facilities of high complexity, however, there are other individual character issues and personal donors who escape both the political and professional action.

However, the role of the multidisciplinary team is to assess the general condition of the patient taking into consideration not only the bio-psychosocial conditions but the socio-economic and cultural can be contraindication to transplantation.

In certain situations, after a multidisciplinary patient evaluation may be deemed unfit for transplantation to improve these conditions and here is the whole question of the importance of social determinants for the protection and recovery of health and even the role of the social worker who is capture the multiple forms of social issues, to intervene at the level of network services so that the situation can be overcome and make situations such as lack of decent and sanitary housing, access to good nutrition among others, no longer a barrier to transplantation.

The intervention in these determinants is essential to overcome the limitations imposed on users at the time of the most complex procedures and require a decision of the multidisciplinary team and within that team the role of the social worker is to identify factors that may influence the smooth progress of the transplant.

\section{Conclusions}

From the above discussion multiple forms of social issues and professional intervention of social worker, has recreated new ways to intervene, to look at the subject in the protection and recovery of health. From this perspective, the analysis of the data indicates the place and the importance of the social determinants of health lie in the public policies of health care. The intervention in these determinants is essential to overcome the limitations imposed on users at the time of the most complex procedures and requiring a decision by the multidisciplinary team.

It is concluded that the guarantee of maintaining the health and quality of life after transplantation depends yet on the guarantee of a solid service network and agreed still lacking in the state of Amazonas, because the (in) existence of this may also constitute factors and determinants of health of patients.

This research also concludes that strengthening this intersectional network could guarantee the right to health of those who need to be able to transplant and social and economic issues are now at risk for the quality of care after the procedure.

Liver transplantation protocol of the Medical School of the University of São Paulo to portray the transplant contraindications puts the outpatient follow-up should be done by a multidisciplinary team and makes it clear that the role of the social worker is to "identify factors that may influence the smooth progress of the transplant."

Although not consider that socio-economic and cultural conditions can be absolute contraindication to transplantation, it is believed that in certain situations, after a multidisciplinary patient evaluation may be deemed unfit for transplantation to improve these conditions and at this point is the whole question of the importance of social determinants for the protection and recovery of health.

\section{Conflict of Interests}

The authors declare that there is no conflict of interests regarding the publication of this article. 


\section{REFERENCES}

[1] Ben-Hur. Ferraz-Neto. LIVER TRANSPLANT IN BRAZIL AND RECENT CHANGES. Ver. Fac. Ciên. Avg. Sorocaba, v.2, n.1, p.26-27, 2000.

[2] BRAZIL. Ministry of Health. Ordinance No. -2600, OF 21 OCTOBER 2009. Approves the Technical Regulation of the National Transplant System.

[3] ESCOBAR, Herton. More severe cases will have priority in liver transplantation. O Estado De Sao Paulo Newspaper, Sao Paulo March 23, 2005.

[4] GOVERNMENT changes the criteria for liver transplantation. O Estado de Sao Paulo - Online Notebook, São Paulo, March 28, 2005.

[5] Iamamoto, MarildaVillela. Social work in conteporaniedade: work and training - 12. Ed - São Paulo, Cortez, 2007.

[6] OLIVEIRA, Antonia Cosmo. SILVA Heloisa Helena Correa. A Reflection On the National Transplant Organ and Tissue Policy: State of Amazonas experience. Niterói - RJ: ANINTER-SH / PPGSD-UFF 03 to 06 September 2012, ISSN 2316-266X.

[7] National Transplant System. Available at: http://dtr2001.saude.gov.br/sas/dsra/integram.htm> Accessed on: 02 Jun 2014.
[8] LIVER UNIVERSITY - Hospital of the Faculty of Medicine, University of São Paulo, São Paulo, SP. Journal of the Brazilian Medical Association. Vol.44 n.2 São Paulo Apr. / Jun. 1998.

[9] TAMBELliNI, A. T.; SCHUTZ, G. E. Contribuição para o debate do CEBES sobre a "determinação social da saúde": repensando processos sociais, determinações e determinantes da saúde. Revista do Centro Brasileiro de Estudos em Saúde (CEBES), Rio de janeiro, v.3, n. 83 set./dez., 2009.

[10] ALMEIDA FILHO, N. A problemática teórica da determinação social da saúde (nota breve sobre desigualdades sociais em saúde como objeto de conhecimento). In: Saúde em debate, Revista do Centro Brasileiro de Estudos em Saúde (CEBES). Rio de Janeiro, v.3, n.83, set./dez.,2009.

[11] TEIXEIRA, P.F. Uma introdução conceitual à determinação social da saúde. In: Saúde em debate. Rio de Janeiro v.33, $\mathrm{n}^{\mathrm{o}} .83$, p.380/387, set./dez., 2009.

[12] HELMAN, C.G. Cultura, saúde e doença. Artmed, 5.edição, 2009.

[13] GARRAFA, V.; CORDÓN, J. Determinantes sociais da doença. In:Saúde em debate, Revista do Centro Brasileiro de Estudos em Saúde (CEBES). Rio de janeiro, v.3, $\mathrm{n}^{\mathrm{o}} .83$, set./dez., 2009. 